\title{
Geochemical investigations of a Portion of Obhu Hill Marble Deposit Okpella, Edo-State, Nigeria.
}

\author{
Sanni E.B. ${ }^{1}$, Yusuf I. ${ }^{1}$, Umoru A.T. ${ }^{1}$, Osaghae S.O. ${ }^{1}$,Sule T.U.N ${ }^{1}$, Yemi O. ${ }^{2}$ \\ ${ }^{1}$ Department of Minerals and Petroleum Resources Engineering, Auchi Polytechnic, Auchi. \\ ${ }^{2}$ Department of Geology, University of Benin.
}

\begin{abstract}
The Obhu marble deposit is located at latitude $7^{\circ}$ $21^{\prime} 31.2^{\prime \prime}$ to $7^{\circ} 21^{\prime} 34.9^{\prime \prime}$ and longitude $6^{\circ} 25^{\prime} 11.6^{\prime \prime}$ to $6^{\circ}$ $25^{\prime} 18.0^{\prime \prime}$. The geochemical investigations of a portion of the Obhu hill marble deposit was aimed at investigating the reserve estimate in tonnage, rock mass/overburden volume and the geochemical composition of the deposit. This study was conducted by using vertical electrical sounding (VES) geophysical method to obtain the geo-electric parameters of the deposit, and to determine the reserve estimate of the Marble deposit of study area. The result shows that the reserve tonnage is $4.6 \times 10^{6}$ Tons and rock mass reserveloverburden volume ratio is 9:1.The chemical analysis were compared with the RMRDC of Nigeria for each element suitable for production of cement, fertilizer, iron, steel and other industrial uses. The $\mathrm{MgO}$ values of the samples 1 and 2 does not falls within the acceptable value of $6 \%$ of RMRDC, with the exception of sample 3 which falls within the acceptable limit. $\mathrm{CaO}, \mathrm{Al}_{2} \mathrm{O}_{3}$ and $\mathrm{P}_{2} \mathrm{O}_{5}$ values of the samples falls within the acceptable limits of RMRDC and so suggest that the marble can be put to industrial use, while the $\mathrm{Fe}_{2} \mathrm{O}_{3}$ content of sample 2 and 3 makes them probably not best suited for industrial use, except for sample 1 having a lower value of $1.85 \%$.The silica $\mathrm{SiO}_{2}$ content values for the three samples exceeded the recommended standard of RMRDC of $5 \%$. This result reveals that the marble deposit issuitable for most industrial use.
\end{abstract}

Keywords-Geochemical, Geophysical, Reserve estimate, Reserve tonnage.

\section{INTRODUCTION}

The leap in the economic growth of Nigeria and its gradual evolution into the most attractive destination for foreign direct investment in Africa is placing a huge strain on the available natural resources needed to keep pace with the myriad developmental and economic needs of the country. Infrastructural deficit caused by series of factors in the past has obviously exposed the need to invest massively in relevant construction projects to really prepare the country to achieve the much talked about vision $20-20-20$. These has necessitated the exploration of more mineral deposits for such rocks like Marble, limestone and granites, and quarry them to meet the ever increasing demand in the construction and other related industry. Limestone is a sedimentary rock composed largely of the mineral calcite $\left(\mathrm{CaCO}_{3}\right)$, formed by either organic or inorganic processes (Serra, 2006). Marble is a metamorphic rock composed essentially of calcite $\left(\mathrm{CaCO}_{3}\right)$, dolomite $\left[\mathrm{CaMg}\left(\mathrm{CO}_{3}\right)_{2}\right]$, or a combination of the two, with a fine- to coarse-grained crystalline texture (Fatoye and Gideon, 2013). The basement complex terrain of Nigeria in which the site is located is endowed with a host of solid mineral deposits that can be quarried for construction and other purposes.In addition to geochemical studies, geophysical methods have also been successfully deployed in the estimation of reserves in the basement complex.Locally available calcium carbonates are relatively common in many countries of sub-Saharan Africa and are well suited for small-scale mining and processing (Van Straaten, 2002 and Nduwumuremyi et al, 2013). One key challenge is lack of accurate data on the tonnage of rock and mineral deposits, which in turn, accounts for high prevalence of illegal mining activities, (Abdulawalet al, 2017). Estimating reserve and tonnage of mineral resources is a highly methodical process and has been the focus of various discussions, (Downing and Giroux, 1993).

\section{MATERIALS AND METHODS}

\subsection{Study Area Description}

The study area is located at about $2 \mathrm{~km}$ from the main town of Okpella, off the Auchi - Okene Express way in Obhu, Okpella, Edo State, at latitude $7^{\circ} 21^{\prime} 31.2^{\prime \prime}$ to $7^{\circ} 21^{\prime} 34.9^{\prime \prime}$ and longitude $6^{\circ} 25^{\prime} 11.6^{\prime \prime}$ to $6^{\circ} 25^{\prime} 18.0^{\prime \prime}$. The area is a very steep hill, with a $326 \mathrm{~m}$ peak elevation recorded at the site.

2.2 Geology and Hydrogeology of the Study Area

The study area lies within the Precambrian basement complex of Nigeria. The site and its immediate vicinity is an extension of the crystalline rocks of the Southwestern Nigeria. According to Rahaman (1976), the basement rocks of Southwestern Nigeria are made up of Migmatite - gneiss 
- quartzite complex, Schist belt, Charnokitic, gabbroic and Dioritic rocks, Older granites, unmetamorphosed dolerite dykes and basic syenite rocks, and Volcanic and hyperbyssal rock. Specifically at the site, boulders of granite were predominantly scattered across the hill. Quartz and quartzite rubbles, boulders, cobbles and pegmantitic veins and rocks were also seen at the site. Fracturing and weathering are also evident on rocks seen at the site. Two springs that appear to be structurally controlled and likely perennial too, were noticed towards the foot of the site.

\subsection{Sampling and Geophysical Survey}

This study is done by collection ofsamples in the field for chemical analysis. Electrical resistivity sounding (VES) is also conducted to obtain the geo-electric parameters of the deposit, and to determine the reserve estimation of the mineral deposit in the study area, through geophysical data. Figure 1 shows a schematic diagram of the study area showing the VES points. The ABEM SAS 300C Terrameter and other field accessories were used for the geophysical data acquisition. Geographical coordinates and elevation of the VES points shown in Table 1 were taken with the aid of Garmin GPS MAP 76.

A total of four VES data were acquired across the site, using normal and modified Schlumberger array, with an electrode spread [i.e. AB/2] for each VES data was $120 \mathrm{~m}$. Rock samples for laboratory chemical analysis were taken from the field after pitting was done up to a depth of three meters to expose some portions of the outcrop. Samples were then cut to size before being taken to the laboratory for further analysis. A total of three samples were collected for analysis. The Atomic Adsorption Spectrometer method was employed in analyzing the rock samples.

Table.1: Geographical Coordinates and Elevations of Sampled Points

\begin{tabular}{|c|c|c|c|c|c|c|}
\hline \multirow{2}{*}{$\begin{array}{l}\mathbf{S} / \mathbf{N} \\
1 \\
\end{array}$} & \multirow{2}{*}{$\begin{array}{l}\text { VES Point } \\
\text { VES } 1\end{array}$} & \multicolumn{2}{|c|}{$\begin{array}{l}\text { Latitude } \\
{[\mathrm{N}]}\end{array}$} & \multicolumn{2}{|c|}{$\begin{array}{l}\text { Longitude } \\
\text { [E] }\end{array}$} & \multirow{2}{*}{$\begin{array}{l}\begin{array}{l}\text { Elevation } \\
\text { (m) }\end{array} \\
259\end{array}$} \\
\hline & & $7^{\circ}$ & $21^{\prime}$ & $6^{\circ}$ & $25^{\prime}$ & \\
\hline & & $33.9^{\prime \prime}$ & & $12.3^{\prime \prime}$ & & \\
\hline \multirow[t]{2}{*}{2} & VES 2 & $7^{\circ}$ & $21^{\prime}$ & $6^{\circ}$ & $25^{\prime}$ & 323 \\
\hline & & $34.9^{\prime \prime}$ & & $17.0^{\prime \prime}$ & & \\
\hline \multirow[t]{2}{*}{3} & VES 3 & $7^{\circ}$ & $21^{\prime}$ & $6^{\circ}$ & $25^{\prime}$ & 326 \\
\hline & & $31.4^{\prime \prime}$ & & $18.0^{\prime \prime}$ & & \\
\hline \multirow[t]{2}{*}{4} & VES 4 & $7^{\circ}$ & $21^{\prime}$ & $6^{\circ}$ & $25^{\prime}$ & 261 \\
\hline & & $31.2^{\prime \prime}$ & & $11.6^{\prime \prime}$ & & \\
\hline
\end{tabular}

\section{LB} ISSN: 2456-1878

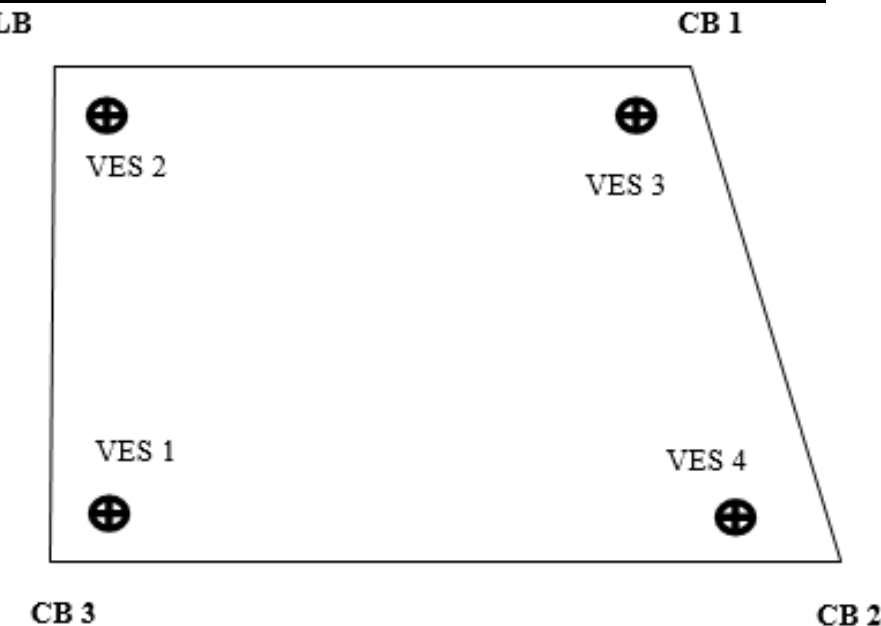

Fig.1: A schematic diagram of the study area showing the VES points

\section{RESULTS}

The geophysical field data from the electrical resistivity sounding is shown in Table 2. The interpreted geophysical data are presented as VES sounding curves shown in fig. 2 and the geo-electric parameters are shown in table 3. For VES 1, a total of five geo-electric layers were delineated. Layer 1 is the topsoil with a thickness of $1 \mathrm{~m}$ and apparent resistivity of $1485 \Omega \mathrm{m}$. The second layer is the subsoil with a thickness of $1.11 \mathrm{~m}$. Layer 3 is highly resistive and is probably a boulder with a thickness of $4.74 \mathrm{~m}$. The fourth layer is deemed to be the weathered basement with a thickness of $6.70 \mathrm{~m}$. The calculated overburden thickness for VES 1 is $11.44 \mathrm{~m}$.

Table.2: Geophysical field data

\begin{tabular}{|c|c|c|c|c|}
\hline \multirow{2}{*}{$\begin{array}{l}\mathbf{A B} / \mathbf{2} \\
{[\mathrm{m}]}\end{array}$} & \multirow{2}{*}{$\begin{array}{l}\text { VES } 1 \\
\text { App Res } \\
(\Omega \mathrm{m})\end{array}$} & VES 2 & VES 3 & VES 4 \\
\hline & & $\begin{array}{l}\text { App Res } \\
(\Omega \mathrm{m})\end{array}$ & $\begin{array}{l}\text { App Res } \\
(\Omega \mathrm{m})\end{array}$ & $\begin{array}{l}\text { App Res } \\
{[\Omega m)}\end{array}$ \\
\hline 2 & 1185 & 598 & 396 & 59 \\
\hline 3 & 1226 & 742 & 436 & 53 \\
\hline 4 & 1301 & 906 & 515 & 49 \\
\hline 6 & 1725 & 936 & 729 & 71 \\
\hline 8 & 2054 & 812 & 1016 & 89 \\
\hline 12 & 2572 & 513 & 1073 & 121 \\
\hline 15 & 2780 & 427 & 1107 & 153 \\
\hline 25 & 2319 & 553 & 1047 & 224 \\
\hline 32 & 1995 & 650 & 1131 & 271 \\
\hline 40 & 1773 & 798 & 1329 & 320 \\
\hline 50 & 1512 & 951 & 1525 & 384 \\
\hline 60 & 1628 & 1204 & 1827 & 425 \\
\hline 80 & 1832 & 1512 & 2319 & 490 \\
\hline 100 & 1965 & 1917 & 2864 & 462 \\
\hline 120 & 2317 & 2230 & 3315 & 537 \\
\hline
\end{tabular}


*App Res - Apparent Resistivity ( $\Omega \mathrm{m}$-ohms metre)

The data trend for the remaining VES points is not entirely similar. Calculated overburden thickness for VES 2, 3 and 4 is $6.89 \mathrm{~m}, 13.64 \mathrm{~m}$ and $45.78 \mathrm{~m}$ respectively. The calculated average overburden thickness for the site is $19.44 \mathrm{~m}$.
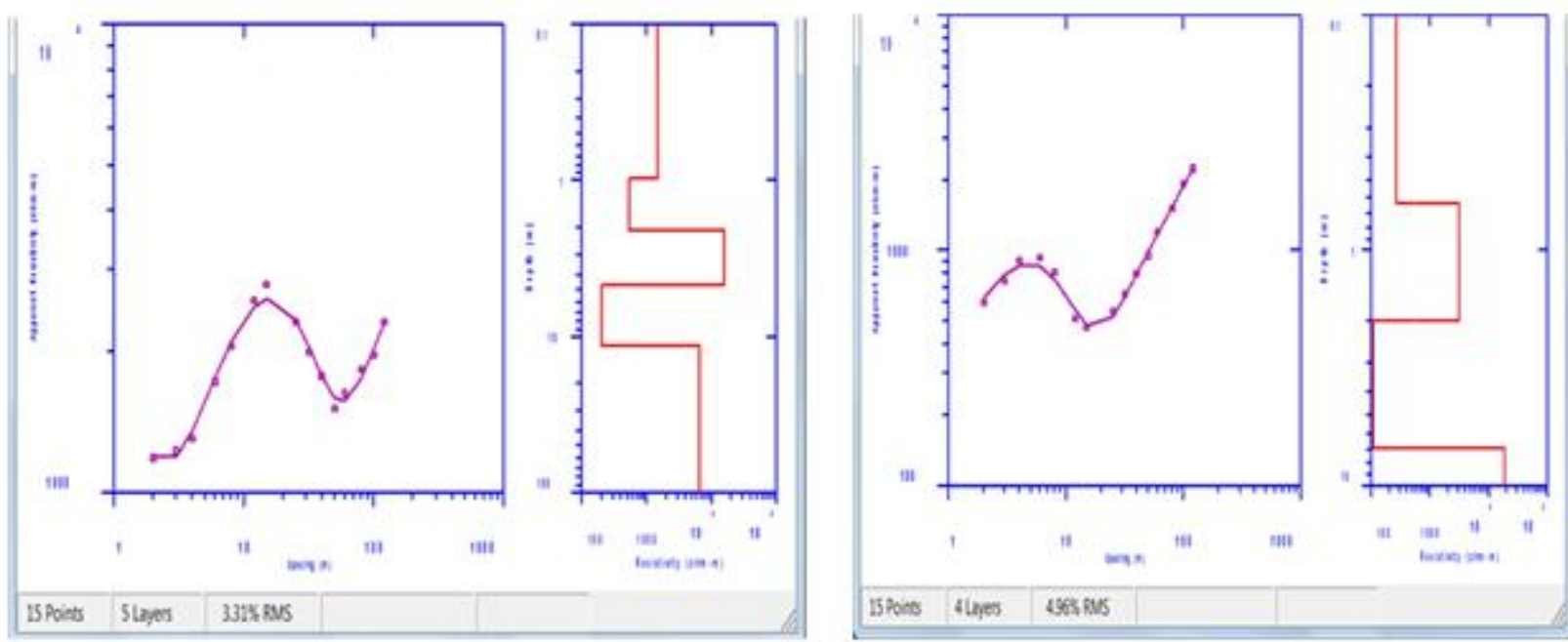

\section{VES 1}

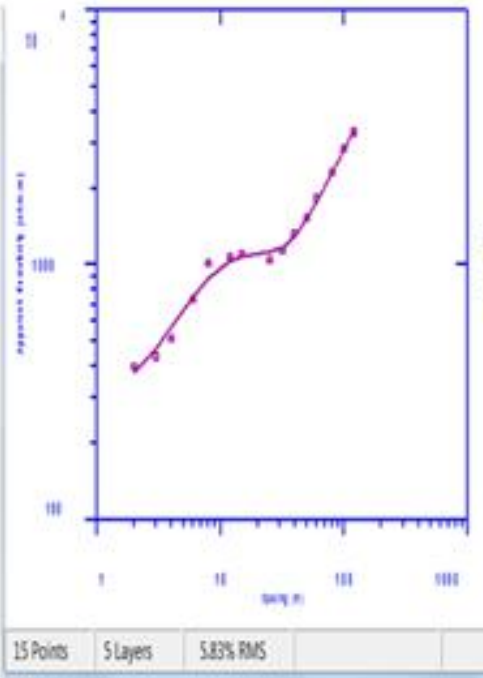

VES 3
VES 2

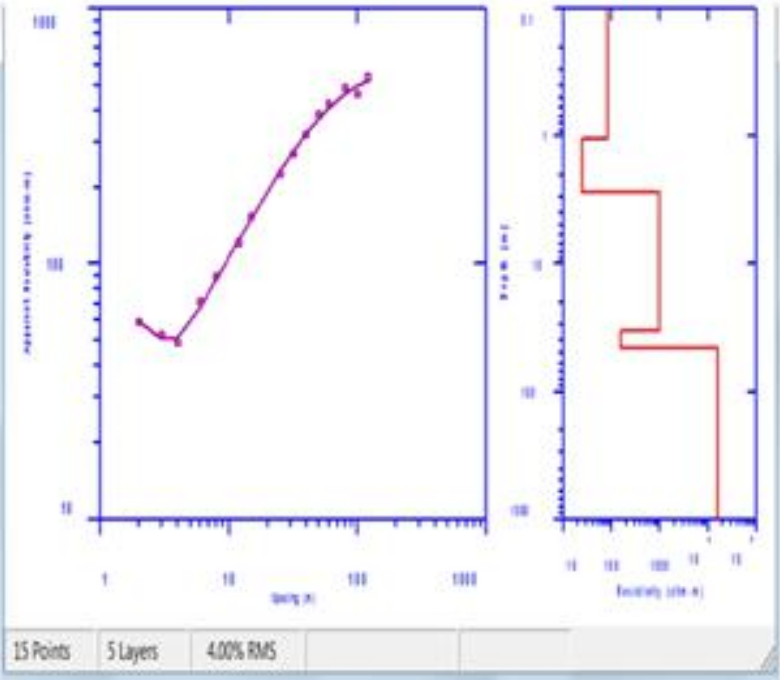

VES 4

Fig.2: VES curves of the resistivity sounding in the study area

Table.3: Geoelectric Parameters and Inferred Lithology from the VES Data

\begin{tabular}{|c|c|c|}
\hline Depth (m) & $\operatorname{App} \operatorname{Res}(\Omega m)$ & Lithology \\
\hline \multicolumn{3}{|l|}{ VES 1} \\
\hline 1.0 & 1,485 & Resistive/lateritic topsoil \\
\hline 2.11 & 538 & Resistive/lateritic subsoil \\
\hline 4.74 & 15,825 & Boulder \\
\hline 11.44 & 202 & Sandy clay/clayey sand \\
\hline$? ? ?$ & 6486 & Fresh basement \\
\hline \multicolumn{3}{|l|}{ VES 2} \\
\hline 0.63 & 264 & Resistive/lateritic topsoil \\
\hline 2.00 & 3,145 & Resistive/lateritic subsoil \\
\hline
\end{tabular}




\begin{tabular}{lll}
\hline Depth $(\mathbf{m})$ & App $\operatorname{Res}(\mathbf{\Omega m})$ & Lithology \\
\hline 6.89 & 109 & Weathered layer \\
$? ? ?$ & 18,265 & Fresh basement \\
VES 3 & & \\
1.92 & 316 & Resistive/lateritic topsoil \\
4.20 & 4,887 & Resistive/lateritic subsoil \\
6.94 & 583 & Weathered layer \\
13.64 & 314 & Weathered basement \\
$? ? ?$ & 33,734 & Fresh basement \\
VES 4 & & \\
1.04 & 82 & Resistive/lateritic topsoil \\
2.78 & 24 & Resistive/lateritic topsoil \\
33.78 & 998 & Fresh bedrock \\
45.78 & 154 & Weathered/fractured layer \\
$? ? ?$ & 16,135 & Fresh basement \\
\hline
\end{tabular}

\subsection{Reserve Estimation}

The estimation of tonnage is derived from elevation and the overburden thickness of the area. The top surface elevation (ordinance datum) of the underlying fresh bedrock of the site is obtained by subtracting the overburden thickness from the surface elevation at each VES point.

3.2 Reserve Volume

Reserve volume $=$ Area of the site $\left(\mathrm{m}^{2}\right) \mathrm{x}$ thickness [trapezoidal height] of the bedrock.

Therefore, the reserve volume $=25,484 \mathrm{~m}^{2} \times 71=1.8 \times 10^{6}$ $\mathrm{m}^{3}$

\subsection{Reserve Tonnage}

This is the product of the reserve volume and the specific gravity of the bedrock. Taken the specific gravity of the bedrock at the site [Marble] to be 2.55 , therefore the reserve tonnage is given thus:
Reserve tonnage $=$ Reserve volume $\mathrm{x}$ specific gravity

$$
=1.8 \times 10^{6} \mathrm{~m}^{3} \times 2.55=4.6 \times 10^{6} \text { Tons. }
$$

Overburden volume is the product of the average overburden thickness of the site and the trapezoidal area Overburden volume $=19.44 \mathrm{~m} \times 25484 \mathrm{~m}^{2}=495,408.96 \mathrm{~m}^{3}$ Therefore, rock mass reserve/overburden volume ratio $=$ 9:1.

The chemical analysis results of the marble samples from the study area are shown in table 4. It was compared with the Raw Materials Research and Development Council of the Federal Ministry of Science and Technology standard for each element suitable for production of cement, fertilizer, iron, steel and other industrial uses.

Table.4: Marble Analysis Result from the Study Area

\begin{tabular}{lllll}
\hline Parameter (\%) & Sample 1 & Sample 2 & Sample 3 & $\begin{array}{l}\text { FMS (RMR\&DC) Standard } \\
2011(\%)\end{array}$ \\
\hline $\mathrm{MgO}$ & 5.24 & 3.98 & 6.11 & 6 \\
$\mathrm{CaO}$ & 71.63 & 81.17 & 76.53 & 54.28 \\
$\mathrm{~K}_{2} \mathrm{O}$ & 2.75 & 1.64 & 1.22 & - \\
$\mathrm{Fe}_{2} \mathrm{O}_{3}$ & 1.85 & 2.07 & 2.51 & 2 \\
$\mathrm{Al}_{2} \mathrm{O}_{3}$ & 3.11 & 2.98 & 3.46 & 1.25 \\
$\mathrm{SiO}_{2}$ & 8.54 & 6.32 & 7.43 & 5 \\
$\mathrm{P}_{2} \mathrm{O}_{5}$ & 0.71 & 0.69 & 0.74 & 1 \\
\hline
\end{tabular}

Most of the values agree with the quality standard set by the Raw Materials Research and Development Council (RMR \& DC) for industrial purposes. Many industrial application of marble require limits on levels of specific purities $(\mathrm{MgO}$, $\mathrm{SiO}_{2}$ and $\mathrm{Fe}_{2} \mathrm{O}_{3}$ ). The $\mathrm{MgO}$ values of the samples 1 and 2 does not falls within the acceptable value of $6 \%$ of
RMRDC, with the exception of sample 3 which falls into the acceptable limit, and it probably could be accepted for the industrial purpose it is to be put into with some strict regulation of production test control upon further studies or examination. $\mathrm{CaO}, \mathrm{Al}_{2} \mathrm{O}_{3}$ and $\mathrm{P}_{2} \mathrm{O}_{5}$ values of the samples falls within the acceptable limits of RMRDC and so suggest 
that the marble can be put to industrial use as regards its $\mathrm{CaOAl}_{2} \mathrm{O}_{3}$ and $\mathrm{P}_{2} \mathrm{O}_{5}$ content. The $\mathrm{Fe}_{2} \mathrm{O}_{3}$ content of $\mathrm{a}$ maximum $2 \%$ indicates that sample 2 and 3 having values of $2.07 \%$ and $2.51 \%$ respectively are probably not best suited for industrial use, except for sample 1 having a lower value of $1.85 \%$. However, it should be noted that samples 2 and 3 values are on the bother line as well and as such the marble may well pass for use under strict test regulation regime. The silica $\mathrm{SiO}_{2}$ content values for the three samples exceeded the recommended standard of RMRDC $5 \%$. These high values suggest that the marble deposit may not be very suitable for industrial purposes as it will have a high wearing effect on machineries to be used for its processing.

\section{CONCLUSION}

An estimation of the limestone reserve of the deposit at Obhu, Okpella Edo state, has been evaluated based solely on geophysical data. The reserve tonnage and rock mass to overburden volume ratio depict the site as having good prospects for quarrying.From the chemical analysis done, it is noted that the samples though suitable for most industrial use, but would probably be abrasive to machines because of its high silica content. A detailed pilot test should therefore be carried out using the limestone deposit, depending on the use to which it is going to be put to. Also, a coring program should be embarked upon so as properly establish the nature and extent of overburden in the area.

\section{REFERENCES}

[1] Abudulawal, L., Amidu, S.A., Adeagbo, A.O.,\&Adejumo, A.S. (2017). Overburden thickness and potential tonnage estimate of Olode-Gbayo pegmatite deposit, Southwestern Nigeria, using electrical resistivity method. Journal of Geography, Environment and Earth Science International, 10(2), 1-12.

[2] Downing, B.C.,\& Giroux, G. (1993). Estimation of a waste rock ARD, block model for the Windy Craggy massive sulfide deposit, Northwestern British Columbia.Journal of Exploration and Mining Geology, 2(3), 203 - 215.

[3] Fatoye, B.F.,\& Gideon, Y. B. (2013). Geology and occurrences of limestone and marble in Nigeria. Journal of Natural Sciences Research, 3(11), 6065.

[4] Nduwumuremyi, A., Mugwe, N.J., Rusanganwa, C. A.,\&Mupenzi J. (2013). Mapping of limestone deposits and determination of quality of locally available limestone in Rwanda. Journal of Soil Science and Environmental Management, 4(5), 87-92.
[5] Rahaman, M.A. (1976). Review of the Basement geology of Southwestern Nigeria in geology of Nigeria (pp. 41- 58). Nigeria:Elizabethan Publishing Company.

[6] Raw Materials Research and Development Council(2011). Technical brief on minerals in Nigeria limestone/marble. RMRDC, Abuja, 1-17.

[7] Serra, R. (2006): Dictionary of geology. New Delhi:Academic (India) Publishers

[8] Van Straaten, P. (2002). Rocks for crops: Agro minerals of sub-Saharan Africa.Nairobi, Kenya: ICRAF. 